\title{
The protracted exodus of migrants from Hyderabad in the time of COVID-19
}

\author{
Ipsita Sapra ${ }^{1} \cdot$ Bibhu P. Nayak $^{2}$
}

Accepted: 5 April 2021 / Published online: 6 May 2021

(c) Institute for Social and Economic Change 2021

\begin{abstract}
The immediate aftermath of the COVID-19 pandemic in India saw a mass movement of people, mainly from the cities and large towns to the villages. The lockdown announced by the government abruptly suspended the instrumental value of the city for the millions of migrant workers inhabiting these. As the lockdown period extended, with very uncertain means of inter-state public transport, desperate migrant workers took to the streets in large numbers undertaking arduous and often dangerous journeys to their places of origin. The media highlighting the plight of the migrants elicited responses from different sections. This paper is an exploration of the role of the state and its institutions, civil society and the judiciary in responding to the migrant crisis in the city of Hyderabad, a hub of migrant workers. Closely following the silences and pronouncements of the institutions and analysing the role of each of these over the different phases of the migrant crisis, the paper asserts the need for a closer scrutiny of the universal role of the state response during the migrant crisis.
\end{abstract}

Keywords Migrant workers $\cdot$ State $\cdot$ Civil society $\cdot$ Judiciary $\cdot$ Universalism

\section{The pandemic, lockdown and migrant workers}

The COVID-19 pandemic has put countries across the world in a state of panic. On one hand, the suddenness of the pandemic with a high number of cases and deaths has taken the governments with surprise. On the other, very little was known about the disease and understanding pertaining to spread and containment is still emerging. This has impacted policy-preparedness with a dearth of scientific information that could adequately inform response to the pandemic. As such, the wider approaches of the

Bibhu P. Nayak

bibhuprasadnayak@gmail.com

Ipsita Sapra

ipsita.sapra@gmail.com

1 School of Public Policy and Governance, Tata Institute of Social Sciences, Hyderabad Campus, Hyderabad, India

2 School of Livelihoods and Development, Tata Institute of Social Sciences, Hyderabad Campus, Hyderabad, India 
governments, the belief systems that have underscored such approaches and the institutional arrangements to address the crisis have evolved over time. This is of critical importance in countries like India, where COVID-19 is not just a public health crisis, but a pandemic with socio-economic consequences of an intensity that has pushed millions into poverty and distress (Kesar et al. 2020; Ceballos et al. 2020; Mishra 2020; Adhikari et al. 2020; Chen 2020 among others). While several data points have captured this, the most visible account has been presented by the migrant crisis that India witnessed in the early months of the pandemic (Ray and Subramanian 2020). Migrant workers though played a key role in India's growing urban economy have been excluded from most benefits in the cities, including access to social security programmes and have been subjected to precarious living conditions with many living in makeshift shanties on the worksites or cramped slums (Chandrasekhar and Mitra 2019; Kundu 2009). With estimates pointing to close to 40 million migrant workers in the country, more than the size of the entire population of Canada, the phenomenon calls for closer scrutiny.

The city of Hyderabad has been a home to a large section of migrant population attracted by the IT boom and the associated real estate development that the city witnessed in the 1990s. Migrant population constitutes 67 percent of the total population in the city with 7.1 percent those being interstate migrants (Bhagat et al. 2020). The city is dotted with hundreds of labour addas (referring to pick up points for both skilled and unskilled daily wage labours). Goswami Vernal et al. (2014) indicate four major geographical concentration of migrants in the city in Sultan Sahi (close to Charminar), Syed Nagar (Banjara Hills), Secunderabad Cantonment area and Nallakuntla. Across these locations, Bengali workers in Maggam (hand embroidery work), workers form Odisha in the hospitality industry as well in the Brick kilns dotting the peripheries of the city, workers from Bihar, Uttar Pradesh and Chattisgarh in zardosi (a form of embroidery), footwear making, bangle making, cooking in addition to the real estate sector, have all been an important part of the growth story of Hyderabad.

This paper is an attempt to understand the role of actors and institutions in managing this exodus - the state, specifically the bureaucracy, the railways and the police; the judiciary, specifically the High Court of Telangana and the loosely formed citizens association under the umbrella of civil society. The paper is based on the observations and insights generated from the engagement of the authors in the activities to organize relief and support services to the migrants exiting the city of Hyderabad, a hub for a large number of migrants from the states of Bihar, Odisha, Chhattisgarh, Jharkhand, West Bengal, Maharashtra, Assam and others. In addition, the authors have interviewed members of the civil society organizations - both formal and informal as well as individuals associated with relief work. The study is also based on insights of the interactions with bureaucrats including railway officials, police officers and corporate sector professionals who were associated with relief work. The authors also interacted with a large number of traveling migrant workers, both men and women. The paper analytically and temporally divides the exodus from Hyderabad in Telangana into three phases and as such the paper is structured in three sections, each of which engages with one phase over some overlaps. Within these phases, the role of the three actors, their interactions, the silences and the pronouncements and the evolving patterns of inclusion and exclusion that defined the state citizen relationship during the period is illustrated. 


\section{The state, judiciary and civil society in the time of pandemic}

The state along with its institutions is ideally expected to be operative in the domain of universalism that reaches all groups failing which all interventions remain partial creating and exacerbating exclusion. The civil society, on the other hand, is expected to be operative in the domain of particularism, reaching out to certain groups (Kumar 1993). The migrant exodus also witnessed the role of two fairly autonomous institutions like the railways and the police, redefined in terms of operating guidelines. While both have played important roles during disasters, during the migrant situation, they were required to assume responsibilities of disease control by managing public movement and mobility. The paper argues that the roles of these actors and institutions kept evolving over the period that saw the exodus. Further, the interaction between them created patterns of inclusion and exclusion. Also, in each of these stages one set of actors was over-determining over the others. While in the first phase, the state was leading most interventions; in the second phase, the civil society collectives took the lead. The third and the final phase saw the judiciary playing the determining role directing state interventions. An important pattern that may be discerned from the three actors and their interaction is a response continuum. It is possible to analytically plot the responses of the abovementioned actors on this continuum with silence on one end and proactive activism on the other. Thus, silences and pronouncements of various intent and intensities can be plotted and the consequences of the same can be analysed.

While the state government appeared to be vocal on certain issues, such as generating resources through centralized mechanisms, strict enforcement of lockdown and surveillance on movement, it seemed rather silent on the migrant issue. In contrast to its expected universal approach, for a long time, there was a denial of the problem itself on the part of the executive. It was rather the judiciary, at least in Telangana, spurred by a proactive association of people, that was vocal through its pronouncements in the form of a series of pro-migrant judgements.

Also, the dynamics of centre-state relationships in a federal structure like ours have implications on the how state responds during the COVID-19 crisis, including the handling of the migrant issue. While there was a push for a greater idea of 'One IndiaOne Ration' through greater portability of welfare schemes, most of the direct interventions were expected to be taken at the level of the state governments. This included both public health interventions and social safety nets for the poorer section of the society including the migrants. On the public health front, the states were responsible for creating quarantine centres for the returning migrants, conducting tests, procurement of protective equipment, oxygen cylinders and ventilators, creating designated COVID-19 hospitals or wards in the hospitals. In the cities, the role of Public Health Institutions was rather limited in the context of migrant worker exodus issue. The states were proactive in terms of reaching out with welfare activities for the migrants such as operating food canteens, food and dry ration distribution, creating employment guarantees in the host states and other welfare activities. All of these while the states were struggling to receive their share of resources from the central kit. Thus, while there seemed to be a decentralization of responsibilities, this was accompanied an alleged centralization of policy responses as well as resources as the centre remained tight-fisted with funds (Agrawal 2020; Burman 2020; Sahoo 2020; Sethi 2020). Taken together, the entire episode of migrant movement post-COVID-19 and the handling of the exodus can be seen as a realignment of the state-citizen relationship. 


\section{Phase I: state as the parens patriae}

The COVID-19 pandemic in India began in February 2020 with the first reported cases in Kerala and by March 2020, the state as well as central governments had announced complete lockdown to control the spread of the disease in the country. The effort to control the spread by regulating the movement of people initiated in Hyderabad when Government of Telangana State ordered closure of commercial establishments on March 14, 2020 followed by closure of educational institutions. The state also leveraged technology-based solutions such as Arogyasetu App and other means for contact tracing and breaking the cycle of virus.

Phase I may be considered the period in the immediate aftermath of the lockdown announced by the Telangana State Government on March 21, 2020 followed by the national lockdown announced by the central government on March 24. This phase was characterized by stringent state control through a strict lockdown that sought to contain the spread of the infection till April 14. The state took on the role of the parens patriae, the legal protector of citizens and asserted political authority that carried the responsibility for protection as a part of the social contract with the citizens.

In this phase, Telangana had two sets of migrants: (1) Those who, despite the inconveniences of an abrupt stopping of cash inflow, had reconciled to 'wait out' the lockdown period hoping for a return to normal after few weeks of difficulties and (2) those who wanted to return to their native villages for such reasons as (a) anxieties regarding contracting infection that was seen largely as an 'urban disease' (b) desperation to re-unite with family in the face of a pandemic, (c) concern around loss of work and mounting expenses and (d) lack of access to a decent place with basic amenities to stay at home. However, given the restricted movement, most of such plans were scuttled. Those trying to move out were stopped and placed in makeshift shelters.

\section{(a) Role of the bureaucracy}

This stage was characterized by a cautious bureaucracy keen to keep the infection rates down. Till the 3rd week of March 2020, when less than 500 individuals had contracted COVID-19 nationwide (see Fig. 1), all governments were closely watching strategies adopted by others. Prior to the lockdown, the Government of Telangana initiated measures like quarantine facilities and contact tracing of international travellers, celebrity talks for raising awareness. Institutional responses included notifying the State Epidemic Disease Regulation, allocation of funds and creation of facilities for testing, advisory to hospitals, hotels and restaurants, and educational institutions, etc. The days preceding national lockdown also saw slew of measures by the state government that included a weeklong lockdown in the state (Government Order (GO) 45 dated 22nd March and GO 46 dated 23rd March) with suspension of public transportation facilities, closing down the borders of the state for inter-state travel, restriction of business hours, notification of paid holiday (GO 160 dated 23rd March) and so on. In its efforts to be universal, the government also made provisions for $12 \mathrm{~kg}$ free rice and one-time support of Rs. 1500 for all food security card (white ration card) holders in the state which was announced by the Chief Minister 


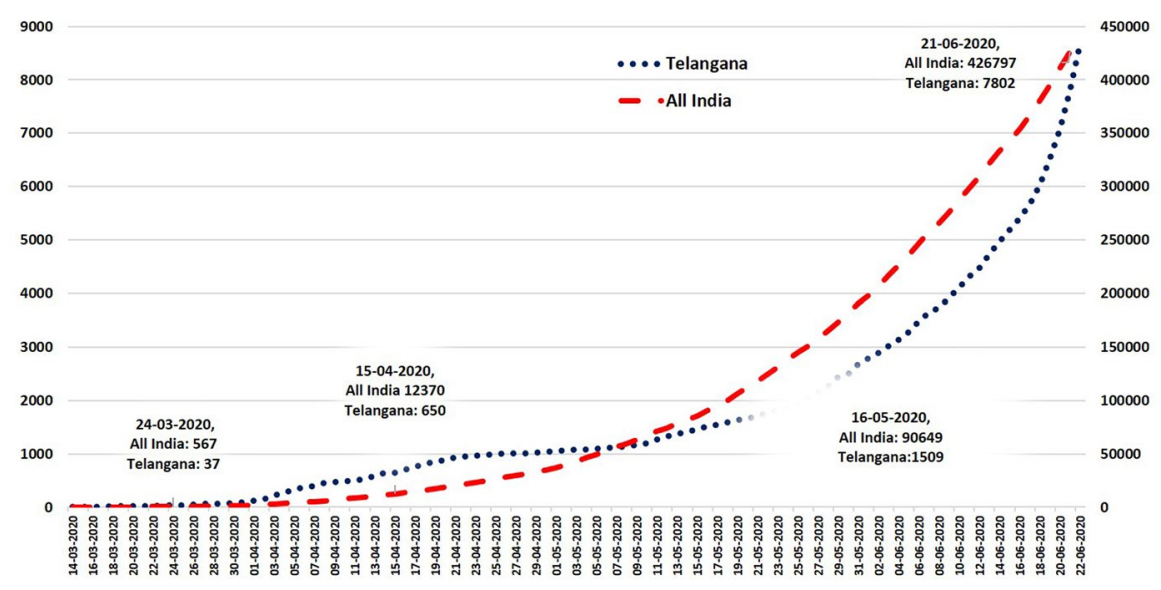

Fig. 1 Number of confirmed COVID-19 cases in Telangana and all India March-June 2020. Source: https:// api.covid19india.org/ last accessed in 24th October 2020

on 22nd March. ${ }^{1}$ With national lockdown, for three weeks, the bureaucracy was geared towards keeping the count low that was sought to be achieved through strict enforcement of state lockdown. However, with the long national lockdown, the urban areas of the state, particularly the capital city of Hyderabad had to face the challenge of managing millions of migrant workers who were now unemployed. Most social security measures such as the public distribution system (PDS) for the state's poor and working classes were out of reach for the large section of migrant workers. In order to extend the domain of universalism to the migrant workers, the Chief Minister of Telangana announced a range of assurances for the migrants in the form of 'packages' on 29th March. These included provision of dry ration (12 kg of rice or wheat flour), and one-time cash transfer of Rs 500 per person. ${ }^{2}$ In addition, appeals were made to land-lords to not insist on rent and defer the same. Similar appeals were made to the employers not to lay-off people during the period.

The state further strengthened cooked food distribution system through the Annapurna Canteens, a subsidized food distribution programme for urban poor by Greater Hyderabad Municipal Corporation started in 2014 in collaboration HKM Charitable Trust. ${ }^{3}$ Specifically, the token Rs 5 charge for the meals was waived off, food distribution was undertaken twice a day (both lunch and dinner), and a number of food distribution centres were increased. CSR support was also used to provide dry ration support and distribute cooked food (by Akshya Patra Foundation) and dry ration and community kitchens (coordinated by T-Social Impact Group) at several points in the city. T-Social Impact Group also worked with several citizen groups and organizations to reach out to the needy not only for dry ration and running community kitchen, but also distribute medicines and provide

\footnotetext{
1 https://telanganatoday.com/telangana-lockdown-12-kg-free-rice-per-person-rs-1500-per-family-to-besupplied-for-each-white-ration-card last accessed on 20th November 2020.

2 https://www.livemint.com/news/india/coronavirus-migrant-workers-in-telangana-to-get-rs-500-cash-and12-kg-rice-each-11585501239262.html last accessed on 20th November 2020.

3 https://www.thenewsminute.com/article/over-1-lakh-free-meals-day-ghmcs-annapurna-lifesaver-hydamid-lockdown-123261 last accessed on 20th November 2020.
} 
transportation to return home later (T-SIG, undated). The district, the city administration and police were mobilized to streamline the process.

In this phase, the police had an extraordinary role to perform-both welfare and enforcement functions. The welfare functions required them to ensure smooth supply of essential items such as food and medicines (including door-step delivery in containment zones that were cordoned-off and all movements prohibited). The police were also engaged in managing shelter homes (function halls turned into temporary shelters) for the migrant workers who were on the streets. The enforcement role saw the police having to use coercive powers to enforce lockdown. As such, reports lauding the police for rising to the occasion went hand in hand with strong criticisms of use of force as a response towards lockdown violations. In addition, a survey was initiated by the Rachackonda Police Commissionerate, in collaboration with the Tata Institute of Social Sciences (TISS) to document the migrants across identified pockets and also to understand their needs. As part of this initiative, police mobilized support for needy migrant workers with cooked food, dry ration, medicines, hospitalization, supply of drinking water and so on based on their needs. So, the police not only facilitated the support for migrant workers and other urban poor mobilized through different government and non-government agencies, but also responded to the need of the migrant workers on its own.

Thus, with a stated commitment towards universalism the state presented a combination of need assessment, welfare and enforcement interventions. As such, the state presented itself as a 'concerned authority, in control of the situation with a plan in place'. The state demonstrated both its willingness and its ability to deliver the social contract with the citizens. With frequent press briefings and GOs, the state made regular pronouncements. While not all of these were inclusive, there was an attempt to reach out to the poor and the distressed, among them, the migrants.

\section{(b) Role of the judiciary: Reactive but pro-migrant}

The judicial response on migrant works issue was rather limited in this phase as state as it started after about a month into the lockdown as a reaction to a series of public interest litigations (PILs). The PILs raised two fundamental questions regarding the role of state in terms of: (1) Honouring the social contract for the migrants who were in Telangana and (2) facilitating smooth return of the migrants to their native places.

The judicial interventions started as a response to PILs in which the petitioners complained about the poor quality of existing shelters and the inability of the state to reach out to the stranded migrants with essential commodities at reasonable prices as promised. ${ }^{4}$ There was another PIL that questioned the state in terms of its ability to protect the fundamental rights of the migrants. It also urged the state governments to provide safe and free transport for the migrants. Thus fundamentally, these PILs underlined the violation of the social contract by the state interrogating the absence of a universal approach resulting in large scale exclusions. Further, these argued that the silence of the state regarding the critical issues of migrant movement exacerbated such exclusion. PILs were thus appeals to the judiciary to use its power to make pronouncements to initiate action by the state.

\footnotetext{
4 https://timesofindia.indiatimes.com/city/hyderabad/telangana-high-court-takes-report-on-skyrocketingvegetables-prices-as-pil/articleshow/74806769.cms last accessed on 20 November 2020.
} 
(c) People's collective

This phase was characterized by sporadic activism by individuals (not only by development professionals and social activists, but also from different walks of life including IT professionals, university/college teachers and students) and organizations (such as Basic Income Network of India, Bhoomika, COVA, Akshaya Patra Foundation, Seva Bharti, PHC and others) of various hues that sprung up as a response to the migrant crisis, moved by the situation and responded to a kind of moral urge to help. Across the city, they mobilized resources to set up food distribution centres at National Highway 44 near Medchal (as some migrant workers started walking home or walked to the highway with the hope of some transport being available) and also at different points in the city. There were also initiatives by city-based citizen groups and cultural organisations from different states (like Odia, Bengali, Bihari, Marathi cultural organisations in Hyderabad) who mobilized support for the migrant workers from their respective states. This was also the stage that saw some volunteer group formation that coordinated over social media platforms such as WhatsApp/Facebook to share information and organize action. Messages over different social media platforms were circulated with phone numbers to which people can call or message for help or to organise help for others. In this phase, direct action was limited to distribution of cooked meals and dry rations. Several concerned citizens tried to lobby with the government to extend support to the migrants. Thus, a loosely formed association was formed within the larger idea of civil society in the realm of particularism and altruism reaching out to disadvantaged groups such as migrants left without work or walking on the roads.

\section{Phase II: The state no longer in control}

The second phase can be considered to have started after a month of the declaration of the lockdown, around the middle of April 2020, when it was getting clear that the lockdown would be extended. Contrary to expectations, the numbers of migrant workers on streets spiralled reinforcing the feeling that lockdown was not a one-time, three weeks shutdown but would be extended indefinitely. The national lockdown that was initially notified till 14th April got extended twice, first till 3rd May and then again till 17th May, thus making migrant workers more distressed and longing to return home. We have considered first and second extension of national lockdown as phase II.

\section{a. Role of the bureaucracy}

This was also that time the state appeared to be struggling with its commitments towards universalism and a grip over the situation with the promised help not reaching a large number of migrants and no visible strategy to combat the situation.

For the migrants, the reassurances by the government about deferred payment of house rent and continued payment of wages, these were difficult to implement as the contracts were between private parties. With no jobs and mounting expenses, the instrumental value of the city eroded swiftly. The construction and factory workers mostly live in the work site or factory premises with minimal amenities using the dwelling spaces for a very limited time. Lockdown forced them to be inside in crowded spaces without any scope for physical distance required for containment. The rising death count and the fear of the pandemic spreading in their congested dwelling spaces, added to their anxiety. As mentioned earlier, 
the fear over the 'city disease' that they had no resource to combat, without the proximity of the loved ones, drying up of savings exacerbated distress among several migrants who were getting desperate to leave. The failure of the state to provide universal support implied that social, economic and food security of the migrants were fast depleting making it all the more difficult for them to cope up with the existential crisis on an everyday basis.

This phase was also characterized by a complete expectation mismatch between the migrants and the bureaucracy: while the migrants were desperate to return, the bureaucracy was primarily concerned over disease control through strict control of movement. So, while the bureaucracy continued to provide relief measures such as food and medicine to the migrants, there was no visible intent to facilitate transport leading to considerable unrest among the migrant workers. Commentators pointed to the inequities perpetuated by the state in allowing private vehicles with some restrictions from first week of May but completely restricting public transport creating patterns of exclusion for a large section of population. The relaxations for movement of cargo vehicle as well as movement of stranded people that allowed towards the end of the first extension and the second extension of national lockdown also made the migrant workers hopeful of returning home. However, lack of clarity on these relaxations and its operational issues among the state agencies coupled with feeling of uncertainties and desperation among the migrant workers have contributed to migrant workers protesting the city. The delay and the uncertainty signalled that the state was not really in control and was without a well-crafted plan. With all kinds of public transport disallowed indefinitely, the migrants, in thousands, took such desperate measures as walking on foot to reach homes thousands of kilometres away. A large number of migrants travelled atop trucks carrying their luggage as these vehicles had the permissions to ply on the national highways. However, they had to shell out an extraordinary amount of money. Also, while it was better than walking, it was quite unsafe and several people actually lost their lives in road accidents.

From the bureaucratic perspective, several states (state of origin for migrant workers) from were still setting up quarantine facilities at the district level for the migrants. As such, the states wanted to exercise strict control on the number of migrants returning to particular districts. In order to streamline the process, trains were planned between origin and destination station without any break in between to ensure greater control on the number of people arriving at pre-decided destinations. While the intent was praiseworthy, this led to enormous delays. In reality, the process of expediently transporting the migrants from the cities to their native places did not really take off the way expected. Thus, despite over 7000 pairs of long-distance trains across the country and a fairly well-developed road transport network with large fleets of state transport corporation buses, the state hesitated to create universal access to safe and efficient transport causing enormous hardships for its people.

An important part of the Phase II was also the initiation, suspension and restarting of the Shramik trains, special rail transport services for the migrants. While the services started, there were multiple confusions.

i. It was not clear who will pay for the train fare, the Central Govt or the State Govts sending and receiving the migrant workers. When introduced, the train fares were higher than the usual as the trains were not run to capacity to allow for physical distance. Following much political negotiations, Shramik trains travel was made free for the migrants.

ii. The efforts of the state to strictly control and regulate movement created significant bureaucratic complexities. The states in which the migrants were located were 
required to send a requisition to the state of origin. The state of origin was then supposed to transfer funds to the railways based on which the trained were to be allotted. Nodal officers were appointed for streamlining and facilitating the process. However, simple as this might seem on paper, it was very complex to execute. While some states were proactive in sending requisitions or responding to requests, others were not. Some states such as Odisha, Chattisgarh and to some extent Jharkhand registered the migrants from their state through different online and offline modes and took special efforts to bring them back. The announcements of benevolent receiving states also raised the expectations and caused frustrations among migrants from states such as Bihar where the government was not seen as equally proactive. Again while some states demonstrated cooperative attitude in coordination of migrant movements, some states had conflictual relationships contributing to the chaos.

iii. Even when trains were allotted, the origins (specific stations) and destination of the trains were not known till the date of departure. While this was ostensibly done as a strategy of crowd management, this created a great amount of anxiety and confusion for the migrants.

iv. The ability to board the train depended on the registration that was done by the police. Each police station was given a stipulated number that they could allot. However, it was not very clear which police station to approach for such registration and there were several reports of migrants being turned away from the Police Stations

Finally, while a large number of migrants left by Shramik trains, these were after prolonged periods of anxiety. Anecdotal accounts narrative that thousands of people left in private buses that charged more than air fares for painfully long and arduous inter-state journeys.

To summarize, this phase was characterized by massive movement of people from the cities to the places of origin. Significantly, interactions with the migrants elicited an erosion of trust in the universalistic role of the state and in interrogation of both the ability and intent of the state in providing safe passage and transport. There were sporadic protests in Hyderabad where the migrants took to the streets to demand permission to return defying lockdown. Conspiracy theories from Karnataka that the industry lobbies were pressurizing the state to restrict movement of workers and anecdotal reports of similar pressures in Telangana added fuel to the crisis and the migrants began to leave in large numbers. ${ }^{5}$

As mentioned, the bureaucratic grip over the situation was to a great extent lost. In terms of the response continuum, while there was a silence in the earlier part of the phase, pronouncements were plenty in the form of several GOs issued by the Ministry of home affairs a little above a month after lockdown, to issue guidelines on migrant repatriation. However, by this time, the migrants were no longer waiting for official permissions to leave. Apart from the police that played a direct role in enforcing lockdown and issuing permissions for inter-state movements, most departments played a rather peripheral role. The universal role of the state was there in intent but certainly not in practice.

\footnotetext{
5 https://www.livemint.com/news/india/karnataka-govt-forces-migrant-workers-to-stay-in-bengaluru-toresume-real-estate-other-activities-11588768995983.html last accessed on 20th November 2020.
} 
b. Role of the people's collective: proactive

It was in this phase of the migrant crisis that the people's collective played its altruistic role in the realm of particularism in a well-coordinated manner. While the nature of the support to the migrants varied, these can be broadly classified into three broad functions.

i. Protective Functions: The protective functions of the collectives included running cooked food distribution at $\mathrm{NH} 44$, the point from which the migrant left Hyderabad. They also provided dry food that people could carry. Interestingly, some sensitive bureaucrats complemented the civil society organizations by using the powers of their offices to set up temporary toilets, water tankers, kits for women and children. However, the entire set of activities was managed by the loosely formed collectives. In addition, learning from the experience of other states where people went hungry on trains, the collectives in collaboration with police and railways, ensured that food was provided on Shramik Trains. The collectives also pitched in to provide dry food packets and water for the migrants for their journey.

ii. Facilitative Functions: The individuals in the collective used their existing formal and informal network with the institutions such as the road transport corporation, railways, police both in origin and destination states to ensure safe transport of the migrant. Some of them also proactively reached out to the nodal officers in destination states with the list of migrant workers in need of transport arrangement and also coordinated with civil society organisations in the destination states to facilitate the travel, food and institutional quarantine. Groups were formed through in different social media platforms across the states to coordinate these efforts.

iii. Direct Action: There was also very little clarity on the trains. The migrants were desperate to leave and were unwilling to wait for the uncertain transport arrangements and have started walking. The response of the individual citizens and the citizen groups was spontaneous. They not only arranged for food, water and shelter for resting for those walking home, but also arranged cargo vehicles when those walking home didn't want to wait. As these cargo vehicles were not plying till destination and were also not permitted to carry migrant workers across the state borders, citizen groups were in involved in keeping track of each groups of migrant workers boarding these cargo vehicles and provide them support till they reach the quarantine centres in their home districts. These required enormous coordination efforts in terms of arranging funds to pay for these cargo vehicles, coordinating with similar citizen group as well as officials in destination states for safe entry to the home state, arrange travel from the state boarder to home district and arranging food and water for the entire journey that sometimes took more than $24 \mathrm{~h}$. These citizen groups were so active that the government officials in destination states often called seeking help for stranded migrant workers instead of their counterparts in Hyderabad.

Individuals and groups also took upon themselves the responsibilities to organise for safe transport of the migrants once it was permitted. After close to two weeks of unsuccessfully trying to organize adequate government transport through trains, the collectives engaged in direct action. They started hiring buses and fund air tickets for the migrants. Members of the collectives, ranging from software engineers to professors to full time social workers, were on the ground to register the migrant workers, segregate them by destination and prepare route plans for the buses. With each bus costing close to Indian Rupees 
$1,50,000$ (around US\$2000), this also required enormous resource mobilization. For the flight's prioritization was done to ensure that groups with vulnerable members such as elderly and children or those with an emergency such as a serious illness or death in the family travelled first. Individuals took upon themselves the responsibility of not just ticket purchase but in guiding migrants to negotiate the maze of rules required to travel which was quite difficult for the first-time travellers struggling with complex processes. Given that the flight mainly connected to the capitals, arrangements were made for supporting the migrants reach their villages. So, remarkable was the impact that some political parties joined hand to claim fame for the initiatives. A tremendous amount of fund raising, coordination and networking led to thousands of migrants being supported to return to the native places. Apart from these travel and food support for migrant workers, there have been several other innovative measures like collaborating with India Post to transfer cash to the migrant workers by INBI, ${ }^{6}$ mobilizing support for migrant workers observing fast in the holy month of Ramzan, reaching out to children of migrant workers with toys and study materials, feedings stay animals in the city and so on.

Needless to say, that on the response continuum, the collectives were proactive and their actions spoke louder than any pronouncement. Extraordinary as this might be, this response was an outpouring of the immediate moral drive that brought people and organizations of diverse hues together. While it was vibrant and addressed some of the key existential needs, such acts of altruism cannot be considered to be a long-term or sustainable way to address the crisis. However, an important contribution of the group was to amplify the concerns of the migrants to the judiciary leading to pronouncements in their favour calling for greater state accountability towards its universal role.

\section{c. Judiciary}

While the first phase was characterized by PILs to the Telangana High Court, the second phase witnessed judicial response to the PILs. The initial state response to the judiciary was that of denial as the advocate general informed the court that several measures were undertaken to ensure that the concerns of the migrants were adequately addressed with close to two lakh migrant workers placed in shelter homes. However, the High Court was not satisfied as it feared significant exclusions and directed the state government to undertake necessary measures to provide shelter and facilities to all migrants. The state government was directed to submit a compliance report by 6th May. ${ }^{7}$ The court also directed the State Legal Services Authority to examine the prices of vegetables and other essential goods and based on an assessment, submit a report by April 29. In addition, the Telangana High Court also directed the state to coordinate with other neighbouring states to facilitate safe return after obtaining necessary permissions in accordance with law. ${ }^{9}$

\footnotetext{
${ }^{6}$ https://www.thehindubusinessline.com/news/inbi-seeks-to-partner-india-post-for-cash-transfer-exper iment/article31724121.ece last accessed in 10 March 2021.

7 https://www.newindianexpress.com/states/telangana/2020/apr/22/what-about-rest-of-migrant-workersduring-covid-19-lockdown-telangana-hc-asks-state-government-2133531.html last accessed on 20 November 2020 .

8 https://www.newindianexpress.com/states/telangana/2020/may/09/act-tough-on-sellers-hiking-prices-ofessentials-hc-tells-telangana-govt-2140999.html last accessed on 20 November 2020.

9 https://www.newindianexpress.com/states/telangana/2020/apr/28/telangana-high-court-asks-governmentwhy-migrant-workers-cant-leave-2136344.html last accessed on 20 November 2020.
} 
These actions were significant given that during the same period, the Supreme Court was led in a very different direction. As the migrants poured out onto the streets with their meagre belongings and stories of their plight was covered extensively in the media, there were PILs filed in the Supreme Court. However, the Supreme Court was satisfied with the governmental response and did not see the need for any cash support to the migrants as was requested in the PIL. This demonstrates that the Judicial pronouncements by the Telangana High Court was in stark contrast to that of the Supreme Court. On the response continuum, the Telangana High Court was proactive, responsive and loud in its pronouncement.

\section{Phase III: proactive judiciary, guided executive}

Phase III of the migrant exodus was distinct from the first two phases in its complete take over by the Judiciary in Telangana. There is period between the 3rd extension of national lockdown starting 18th May to end of June. People's collective, in this stage, was led by lawyers and they invoked judicial activism to direct the bureaucracy to respond in a certain manner. It was a phase when the executive demonstrated less of its own agency and was seen as responding to the direction of the judiciary. Within the bureaucracy, the railways played an important role in streamlining the Shramik trains. The police also had an important role in crowd management in facilitating return. Although the District Administration of Hyderabad was directed to play a more proactive role in providing shelter to the migrants, the collectives allege that the response was slow and insipid.

\section{(a) Role of bureaucracy}

As mentioned, in this phase, the bureaucracy seems to be following the direction of the court that was in turn informed and advised by the people's collective. Further, the institutions demonstrated rigidity and appeared to be protecting their turf rather than demonstrating sensitivity required to respond in the extraordinary situation. The national carriers, Air India, that was so well-utilized in getting Indians stranded abroad through the Vande Bharat initiative, had no programme initiative for the domestic migrants. Individuals who chartered flights for migrant workers reported that no special prices were offered and indeed it was cheaper to charter planes from private players. Indeed, when the private airlines Spicejet offered flights on the migrant routes, there were no takers for the offer from the government.

On the transport front, the collectives also negotiated with the railways in the High Court requesting extra coaches for the migrants in regular trains. However, these were not accepted by the railways citing safety concerns. The railways only agreed for a limited number of emergency quotas to be released for the migrants. While a large number of migrants aggregated in front of the Secunderabad station, the railways refused to allow them to wait inside the premises due to the fear of disease spread and families with young children had to wait outside in open spaces. It was again through PILs, that the District Administration of Hyderabad was asked to house the migrants in nearby function halls. These examples demonstrate the silence that characterized the state and its institutions on the response continuum.

The two areas where the police played a role was in registering the migrant workers for their travel and managing the issue of brick kiln workers. Like most urban metropolises, peripheries of Hyderabad are dotted with brick kilns. Most workers here are brought on contract (that includes travel) from the state of Odisha. The timing of the migrant crisis 
coincided with the usual time of return. Free-riding on the situation, contractors started dropping the brick kiln workers on the Medchal Highways so that they could be transported by the people's collective. However, police played an important enforcement function in dealing with this strictly compelling the brick kilns to honour their initial contract. This was possibly an areas where the state played a visibly proactive role.

(b) Role of people's collective: the litigant

As mentioned, the phase III of the migrant crisis was led by a litigant collective. Indeed, the lines between collectives and the judiciary often got blurred as the collective, through their perseverance and a sound understanding of the ground situation was able to get their recommendations accepted by the Court. Along with this, people's collective was still continuing in providing support to the migrant workers in terms of facilitating for food and water, shelter and transportation. They played an important role in supporting police and administration for smooth operation of Shramil trains. They guided the migrant workers either still stranded or walking to the temporary shelters, volunteered to ensure food and other basic amenities in these shelters, coordinate travel from these shelters and other places to the designated railway stations for shramik trains. Several of them were also coordinating with organisations and Govt. officials in destinations states even after these workers reached destination states but were stuck on the way for some or other reasons.

\section{(c) Judiciary}

This is the phase that was marked by a proactive judiciary at the state level that passed a slew of pro- migrant judgements over a period of two to three weeks.

On May 22nd, the Telangana High Court issued a directive to the state government to take responsibility for the migrants, specifically not drop them on the district border. This was in response to a PIL filed by Prof Rama Shankarnarayan Melkote, a social activist that alerted the $\mathrm{HC}$ regarding the police forcibly transporting the workers in RTC and private buses to the Bhoraj check post in Adilabad on NH-44 on the Telangana-Maharashtra border and sought direction to stop the same. ${ }^{10}$

In addition, in response to an appeal from concerned individuals, on May 30th 2020, the Telangana High Court directed an advocate as amicus curiae to visit the transit camp and appraised the $\mathrm{HC}$ of the situation on the facilities provided including the transport arrangements. ${ }^{11}$ On June 3rd 2020, based on a PIL and the response by the visiting advocate, the High court emphasized that it was the duty of the government to ensure safe shelter for the migrants. The court further directed the government to evolve a comprehensive policy to cover migrant workers stranded not just in Medchal, but across the city. ${ }^{12}$ The bench directed the state government to ensure that the workers are not charged any fare, either by the railways or by the state transport corporation buses. The PILs also prompted the HC to announce on 27 th June, that it will keep a close watch on the migrant situation. Thus,

\footnotetext{
10 https://www.thehindu.com/news/cities/Hyderabad/dont-dump-migrants-at-state-borders-hc/article316 52142.ece last accessed on 20 November 2020.

11 https://www.newindianexpress.com/states/telangana/2020/may/30/telangana-high-court-appointed-lawyer-to-look-into-migrant-crisis-2149895.html last accessed on 20 November 2020.

12 https://www.newindianexpress.com/states/telangana/2020/jun/03/evolve-policy-to-deal-with-migrantworkers-issue-telangana-high-court-2151446.html last accessed on 20 November 2020.
} 
on the response continuum, the Telangana High Court played an important role in active collaboration with the section of the civil society members comprising lawyers to hold the state accountable emphasising its universal role in supporting all citizens.

\section{Thinking through the phases: state, civil society and judiciary}

The International Labour Organization has called the migration-related problems "a crisis within a crisis". Countries like Jordan have used the crisis to come up with comprehensive strategies to improve social security covers for the informal workers. The migrant issues in the immediate aftermath of the COVID-19 situation in India offer an important study of the state-citizen relationship in the context of a public health emergency. This paper has outlined that evolving roles of key institutions of the state with its bureaucratic arrangement of institutions, the civil society and the judiciary in their response to the crisis in the state of Telangana. It is the interaction of these three actors that create patterns of exclusion and inclusion. The paper presents an illustration of the roles of these institutions across three phases of the migrant crisis. It argues that while the state is expected to operate in the realm of universalism, taking initiatives that reach all, the failure to do so limited the scope of such action to state initiative remain rather partial. This is what happened in Telangana.

Throughout the phases, the state, especially at the central level, chose technology-based solutions to what was perhaps a public health problem with deep social consequences/ outcomes. The Arogyasetu App, contact tracing and breaking the cycle of virus through lockdown were all indicative of an approach that relied heavily on such technology-based surveillance that did not adequately engage with an anthropological engagement with the population and their epidemiological characteristics. In situations such as COVID-19, the state is expected to operate on the lines of welfare state, mediating greater inclusion and addressing exclusion through proactive policy pronouncements. However, the experience of Telangana demonstrated once again that, while the migrant workers are critical to the city, they were only included in the labour market, and as such experienced significant exclusions during the critical phases during the pandemic. Their claims to welfare were pronounced by the loosely formed civil society. The normative basis of modern states and its claim on universalism was thus challenged and the area of welfare was adopted by such civil society formations that created 'a public community of citizens vis-a-vis the state' (Halfmann 1998, pp 520).

Importantly, the initial denial and silence of the part of the state regarding the migrant crisis and the pronouncements by first the civil society and then the judiciary further cemented the apprehension about the states inability to play a universal role that has important implications for the state-citizen relationship.

The exodus associated with the COVID-19 situation raised several important and fundamental questions. These were pertaining to power, authority and legitimacy of the institutions. Michel Foucault described the role of government as the "conduct of conduct," i.e., the ways and means to act upon the conduct of others with the intent to direct that conduct to be carried out in a certain way and direction (Foucault 1982, pp. 220-221). Understood this way, government is therefore operationalized through a relationship of power between states and citizens through institutions. However, the migrant crisis in the COVID-19 situation demonstrated the inadequacies in the ability of the state to perform such roles.

It may also be important to think about the state-citizen relationship in this period through the idea of response continuum. Legitimacy of the state, it is often argued, depends 
on the substantive values that are derived and realized by those who accept authority (Fabienne 2017). In this respect, legitimate states claim and exercise authority and the citizens of such states have political obligation. As such, factors that add legitimacy to the state include such components as consent, fair procedures, or its instrumental value (Adams et al. 2019). As the chronicling of the events demonstrate, the state wielded power and control in the first phase of the migrant crisis when it was seen as under control. This phase was also characterised by a degree of legitimacy when the authority of the state was not resisted by the migrant workers. However, with the state seemingly losing its grip in the second phase with increasing numbers and no clear strategy, the migrants, who do not have any political claims on the local legislature, felt the declining instrumentality of a city life. At this point they completely subverted authority undermining rules that the state came up with to restrict movements. By the third phase the role of the state was reduced to following the court orders facilitating transport. Thus, while it would be an exaggeration to say that the state lost its legitimacy, there were serious concerns about the universal and inclusive role that it was expected to perform.

The migrant crisis a defining moment in the state-citizen relationship in India. Across, the phases outlined, the silences of the state were loud and the pronouncements muted. While the exodus was desperate and arduous, the impact of crisis on the political future of the country is uncertain. The enormity of the crisis exposed the inadequacies of the state in creating universal inclusions. With the unlock period being declared, there is a trickle back of the migrant workers to the city as re-opening of economic activity is once again creating the instrumental value of the city. With such measures as welfare portability, the migrants can possibly expect a more sustainable support structure in the cities. The migrant crisis during the COVID-19 situation is an opportunity to understand the enormous gaps in the welfare apparatus of the state. Though the exclusion of urban migrants from the social security and other state support in the cites have been documented and flagged before, the policy response has been inadequate (Rajan and Bhagat 2021; Srivastav 2020; Suresh et al. 2020). It thus calls for a complete over-haul and re-imagination of the role of the state, its institutions and the public policies that can respond to crises in manners that are effective, sensitive and inclusive. The national policy in migrant workers, now being formulated by NITI Aayog must strive to address these concerns.

\section{References}

Adams NP, Scherz A, Schmelzle C (2019) Legitimacy beyond the state: institutional purposes and contextual constraints. Crit Rev IntSoc Political Philos 23(3):281-291

Adhikari A, Goregaonkar N, Narayanan R, Panicker N, Ramamoorthy N (2020) Manufactured Maladies: lives and livelihoods of migrant workers during COVID-19 lockdown in India. Indian J Labour Econ 5:1-29

Agrawal P (2020) COVID-19 and dwindling Indian federalism. Econ Political Wkly 55(26-27):16-19

Bhagat R, Sahoo H, Archana S, Roy K, Govil D (2020) The COVID-19, migration and Livelihood in India a background paper for policy makers. In: International Institute for Population Sciences. Technical report, International Institute for Population Sciences, Mumbai

Burman A (2020) How COVID-19 is changing Indian federalism. https://www.eastasiaforum.org/2020/07/ 28/how-covid-19-is-changing-indian-federalism/

Ceballos F, Kannan S, Kramer B (2020) Impacts of a national lockdown on smallholder farmers' income and food security: Empirical evidence from two states in India. World Dev 136:105069

Chandrasekhar S, Mitra A (2019) Migration, caste and livelihood: evidence from Indian city-slums. Urban Res Pr 12(2):156-172 
Chen M (2020) COVID-19, cities and urban informal workers: India in comparative perspective. Indian J Labour Econ 63(1):41-46

Fabienne P (2017) Political legitimacy. In: Edward NZ (ed) The Stanford encyclopedia of philosophy. Springer, Berlin

Foucault M (1982) The subject and power. CritInq 8(4):777-795

Goswami Vernal T, Priyadarshini B, Nayeem S, Rag P (2014) Migration and conflict in the Mega City: a study of migrants in Hyderabad. Urban India 34(1):87-11

Halfmann J (1998) Citizenship universalism, migration and the risks of exclusion. Br J Sociol 49(4):513-533

Kesar S, Abraham R, Lahoti R, Nath P, Basole A (2020) Pandemic, informality, and vulnerability: impact of COVID-19 on livelihoods in India. In: CSE Working Paper

Kumar K (1993) Civil society: an inquiry into the usefulness of an historical term. Br J Sociol 44(3):375-395

Kundu A (2009) Exclusionary urbanisation in Asia: a macro overview. Econ Political Wkly 44(48):48-58

Mishra HS (2020) COVID-19: reverse migration of labour and the longer road to SDGs, documenting coronavirus pandemic as a news correspondent. In: Disaster management for 2030 Agenda of the SDG. Palgrave Macmillan, Singapore, pp 359-379

Rajan SI, Bhagat RB (2021) Internal migration in India: integrating migration with development and urbanization policies. Policy Brief 12:59

Ray D, Subramanian S (2020) India's lockdown: an interim report. Indian Econ Rev 55:31-79

Sahoo N (2020) COVID19 and cooperative federalism in India. https://www.orfonline.org/expert-speak/ covid19-cooperative-federalism-india-so-far-good-65429/

Sethi S (2020) Covid-19 and Indian federalism: through the lens of the disaster management act, 2005 and fiscal federalism. India Law Journal 2:10

Srivastav R (2020) Integrating migration and development policy in India: a case study of three Indian states. In: WP 03/2020, Centre for employment studies working paper series, Institute for Human Development, New Delhi. http://www.ihdindia.org/Working\%20Ppaers/2020/IHD-CES_WP_03_ 2020.pdf

Suresh R, James J, Rsj B (2020) Migrant workers at crossroads-the COVID-19 pandemic and the migrant experience in India. Social Work in Public Health 35(7):633-643

T-SIG (Undated) COVID19 Relief Report http://csr.telangana.gov.in/Covid19ReliefWork

Publisher's Note Springer Nature remains neutral with regard to jurisdictional claims in published maps and institutional affiliations. 